\title{
Inclusive Education Management in Social Studies Course of Children with Special Needs
}

\author{
Ahmad Samawi \\ Universitas Negeri Malang, Indonesia \\ E-mail:ahmad_samawi61@yahoo.com
}

\begin{abstract}
This study aimed at describing the implementation of inclusive education at the social studies course (IPS/Ilmu Pengetahuan Sosial) in the Department of Special Education. The method used was qualitative in term of case studies. The research subject was the student of Special Education Department consisting of four blind students and 60 regular students. The instrument used was the observation, interviews and documentation. The mechanical analysis of data validity was triangulation. The result found that the inclusive education was not difficult to apply well in the IPS course. Students' learning activities in the classroom were very dynamic discussion about the IPS subject and the IPS learning practices in the micro class. The visually impaired student results were not inferior for regular students. It was concluded that inclusive education can be well applied in the IPS course.
\end{abstract}

Keywords: inclusive education, social studies course, children with special needs

One of the goals of the Millennium Development Goals (MDGs) is the realization of as Education for All (EFA), namely education without discrimination and must cover all ages including children with special needs through special education. The General Director of Basic Education at Education Ministry, Hamid Muhammad says enrollment rate of school for children with special needs is still low at only $10-11$ percent of the total amount of 1.6 million children with special need in Indonesia (Kemendikbud, 2015). There is no reason to reject them stay in school, there should be no reason to deny them, to enhance the childrens' participation in school need readiness for both school and teachers in implementing inclusive education.

According to Andajani (2016), inclusive education can be implemented as follows: (a) planning according to the ability of learners, (b) the source and medium of learning that can stimulate all students without exception, (c) learning management group that is able to work in learning, and (d) provision of direct assessments of learning outcomes of blind children. According to Morina (2016) the success of children with special need in learning requires policies, strategies, processes, and actions of inclusive education to help all students succeed in learning.

Since being Established in 2010, Special Education Department (PLB/ Pendidikan Luar Biasa), State University of Malang has 560 students and 240 of them are graduated students. They are now working as a teacher both at special schools or public schools that provide inclusion education. One of the graduated students are blind. Nowadays, this department has
6 students with special need consisting of visual and hearing impairment, mild autism and a mild mental retardation. They study together with regular students. The lecturers consists of eight full-time lecturers with qualification of special education, 13 lectures from (part-time) outside the department. They have a multidisciplinary competence.

The PLB curriculum using the national qualifications framework (KKNI/Kerangka Kualifikasi Nasional) includes personality development course, scientific expertise course, work skill course, and live together course. One of the scientific expertise course is Social Studies (IPS/Ilmu Pengetahuan Sosial) for children with special needs (ABK/Anak Berkebutuhan Khusus). This course aims to develop students' understanding of the concepts and theories, attitudes, and skills of social studies lesson for ABK in special school (SLB). The students not only acquire knowledge and theory, but also at have been practicing in the micro social study lesson since their friends with special needs students among of them.

The view of the IPS is diversed and different. Some students regard IPS as a collection of social sciences and the others are calling it as a social study. The definition of IPS can generally be described as the science that the material comes from the social sciences, humanities, natural sciences oriented for educational purposes in schools. The IPS material is derived from the social, humanities, natural sciences and contemporary events (Marsh, 1991). The all understanding is complementary one another. Therefore, it is necessary for the management of inclusive education in social 
studies learning for ABK. This study aimed to describe the planning, implmenting, activities, interactions, and evaluate the implementation of inclusive education in social studies learning for ABK at PLB.

\section{METHOD}

The research is a qualitative with case study design. The subject of research was the 60 students of PLB UM taking course of ABK learning social studies. They were grouped into two offering (classes). The presence of the researcher became an absolute necessity because the researcher is an instrument. The data collection was done by full participation observation in learning. The other data were collected by documentation in the form of reports, papers and some documents generated from studnts such as lesson plan (RPP/Rencana Program Pembelajaran). Guidance interviews were also conducted via in-depth interviews with snow ball from one to the other students to find hidden data in student learning activities. The data analysis technique was conducted with descriptive techniques.

\section{FINDINGS AND DISCUSSION}

\section{Findings}

Learning social studies in PLB UM was implemented in two offering (classes). For each class consists of regular and visually impaired students. They were $70 \%$ women and $30 \%$ men. The principle of inclusive education used in IPS study are: (1) in accordance with the characteristics of students, (2) democratic or equality, (3) empowerment, (4) the availability of learning resources, and (5) learning materials. The inclusion learning has already begun since in planning, implementation, and evaluation of learning.

\section{Learning Activities of Inclusion Student}

Learning activities with a discovery and inquiry model is classified into very good when the students' presentationof the material and instructional practices is very high. The activity start from reconstructing exploratively in compiling the material of the task until discussing the results of the practice. The students help and complement each another in learning activities.

The students' activities were not only in preparing the paper, but also collecting field data. They were active into the field such as schools, social institutions and community for nursing blind students to collect material data in composing papers.

\section{Learning interactions}

Inclusive learning interaction at ABK IPS lecture is multidirectional. The interactions include: (a) the interaction between the lecturer and students, and vice versa, (b) the interaction among students on a reciprocal basis, (c) the interaction between lecture and students with learning resources. The learning resources include not only books and on-line electronics, but also some resources outside the classroom. For example, the students interviewed "massage service life" in a blind nursing in Malang. In addition, the students observed people's lives in the near-river area (DAS/Daerah Aliran Sungai) Brantas in Malang city.

\section{Evaluation of ABK IPS Learning}

At the end of the course it was conducted final test (UAS/Ujian Akhir Semester). The results of UAS $(30 \%)$ was combined with the midle test (UTS/Ujian Tengah Semester) (25\%), attendance (15\%), activity (15\%) and task (15\%). The comprehensive learning assessments result got (10\%), it was classified into very praise, the majority $(75 \%)$ received very satisfactory, and others (15\%) got satisfactory.

\section{Discussion}

The IPS lesson plan prepared in accordance with the characteristics of student inclusiveness. The planning was prepared to study for one semester presented in 16 sessions. The activities planned for one semester were 14 learning sessions and twice exams in term of the midle-test at $8^{\text {th }}$ meetings and final test at $16^{\text {th }}$ meeting.

The IPS learning model used is discovery and inquiry. According to Joyce \& Weil (2000), discovery model is a learning model that provides greater opportunities for learners to explore and find facts, concepts, and principles of science. The student can explore some resources of social studies learning such as at the library and in the community. While inquiry model is a study that provide opportunities for students to find their own facts, concepts, and principles through activities that have been planned in advance. This model is intended to empower students for exploring, organizing, reconstructiing, and the presentation of material that has been learned. The lectures was organized into two parts. The first was the presentation of the SLB IPS material in the reguler class, and the second was teaching practice in the micro teaching class. The students were devided into 6 groups of inclusion class. Each group received the IPS SLB material to be presented in class discussion and practice through peer teaching in the PLB micro laboratory classroom.

The evaluation of learning was designed into autenthic assessment. The assessment is not only based on the test results at the middle and final semester, but also an assessment of the work in the form of papers 
and RPP of SLB IPS. The students' performance was also assessmented especiall when they were presenting papers in the discussion and practice of social studies lesson in micro class. The learning activities in the classroom such as attendance and participation in the frequency of asking, responding, communication of opinions, and attitudes in the discussion were part of assessment. Cooperation and on-time in submiting assignment were also taken into consideration in the assessment. The middle and final tests were done in the classroom, and the results were collected when the period test was ended. Students with visual impairments submited their task in term of soft file sent via email address to the lecturer.

Learning activities in the first meeting was conducted by giving a lectureing draft for students. The lecturer and students formulated and made agreement on the rules tuition for one semester. The lecturers delivered lecturing system with discovery and inquiry learning model. Lecturing activities were grouped into two parts such as the presentation of conceptual material about IPS and learning in special schools, and peer teaching practices in the micro-teaching classroom. Learning materials were given to students in the classroom for discussion at the third until seventh meeting. For two weeks, students explored the material IPS on line, in the library, as well as in public life.

At this first meeting, the students also classified themselves in some groups. For each group consists of 5-6 students, so it was obtained five groups gained the topics to be discussed. The material topics were given at the first meeting with the expectations of the students obtaining adequate opportunity to seek and find and prepare material to be presented in class discussions. For two weeks, the students continued to be given the opportunity to consult when facing problems and difficulties so that from the beginning has been known and addressed.

IPS theoretical conceptual material discussed together at the second meeting. The basic concepts of IPS is discussed substantively on the IPS scientific orientation and learning in SLB. Definition, objectives, scope, learning model of ABK IPS became focus in this second meeting. In addition, the lecturer also monitored the progress of the implementation of the students' tasks. The papers on the construction of each group were then be presented in class discussions as scheduled discussion organized by students themselves. Presentation of papers was held at the third until the seventh meeting. The middle test was in eighth meeting.

The Structure of class was set with semi-circular shape according to the principles of democratic, active, interactive, and each of the participants can see one another and nothing is in back to his friend. The implementation of the first discussion, the group were presenting the material with a power point program (PPT) LCD assistance. The students seemed hesitant when They present, respond to, ask, and answer questions. Students with visual impairments often ask questions about how the implementation of IPS concept discussed was in ABK learning at SLB. However, the implementation of the next group discussion, the students had courage to express in responding, asking and answering questions. It seems that they were "arguing" when responding, asking and answering questions in the discussion. During class discussions, the students were actually active in learning. Activeness of students in the learning of this group is equal to the research found by Khalid (2010) which states that the learning outcomes of geography are very significantly different between cooperative learning and conventional.

In the second part namely from $9^{\text {th }}$ until $14^{\text {th }}$ meeting, ABK IPS Learning was done in learning practices. For each group had the opportunity to apply ABK IPS learning model in the micro class. This micro classrooms was designed into two parts namely the practice room and the observation room. The practice room is designed with a size of $5 \times 8$ meters or 40 square meters. Practice classroom walls are made of one-way glass screen (one viewing direction). The class is carpeted in gray, equipped with table chairs blend of 5 pieces, table and teacher chair at the left front corner, and an LCD, whiteboard, bright lights and air conditioning. When one group was practicing a learning, then another groups made observations in the observation room so that the observed group was not disturbed. After completing ABK IPS learning practices in accordance with the theme and levels or classes and types of SLB that was selected, then the other groups gave comments, feedback, questions and discussion of results of observation of the practice.

When a group of blind students was practicing at inclusive learning, a blind student acted as a IPS teacher with inclusion student. She was wearing a white shirt with a combination of colorful matching jacket and skirt, tied curly hair at the back, standing in front of the class to act out as a IPS teacher. Sometimes her hands raised upward move to the right and left, as if giving a verbal motion to clarify the description in learning. Other times, her hands touched braille books to recall the content to be studied. 'The teacher' let students ask, "hi kids, please, ask". When a a student gave question, 'the teacher' asked the student stepped closer, holding his hand and said, "like this son ..." It was obvious 'the teacher' (the blind student) were very appreciate the role that the learning atmosphere to be alive and interesting. In certain time, the co-teacher also helped preparing and providing the necessary learning material in the classroom. 


\section{Learning Activities of Inclusion Student}

The discussion activities were are very high, as they faced one another in face to face, so that, if one or some of them were not active would be appeared. In the micro classroom observation, all the faces toward the practice room, and occasional the observers laugh at their friends' behavior in the practice. The results of observation, then, became referred to respond practitioner group, whereas the observed group gave respons. Then, the results of discussions on instructional practices was used as a reference for revising the lesson plan before it was submitted for the lecture.

\section{Learning interactions}

The participant collegues consisting of the regular and blind students also increased the sincerity of interaction, so that the students have the commitment and concern to others and better appreciate his role as a teacher candidates of SLB. This is consistent with research from Atmoko (2011) which states that the confidence will determine the stability of the emotions and actions as well as empowering the teachers in learning.

\section{Evaluation of ABK IPS Learning}

The obtained results of the study showed that inclusion education can be successfully implemented in the course of learning ABK IPS. Based on some components of the assessment given earlier in the begining semester, the students agree with learning outcomes that have been acquired. The acquisition of the learning outcomes was achieved by authentic assessments of inclusion students in the classroom.

\section{CONCLUSION AND SUGGESTION}

From the data analysis above, it can be concluded that inclusive education in good management can be performed well in ABK IPS in the Department of Special Education UM. It has been seen from the planning that empowers students, implementation, monitoring and evaluation of a comprehensive study. The student results are not only obtained through tests but also authentic assessment that there is satisfaction in receiving the results of their study.

Suggestion for educators in implementing the insclusion instructional, they should make planning, implementation, monitoring and evaluation of learning process comprehensively. Human care and commitment as well as emotional stability will foster self-confidence of educators and learners.

\section{REVERENCE}

Andajani, S. J. (2014). Penerapan pembelajaran orientasi dan mobilitas untuk pengembangan kompetensi guru pada taman kanak-kanak inklusif. Jurnal Penelitian dan Pengembangan Pendidikan Luar Biasa, 1(2), 150-157.

Atmoko, A. (2011). Model tindakan guru menanggapi perilaku siswa dalam pembelajaran. Jurnal Ilmu Pendidikan, 17(4), 255-264.

Joyce, W. B. \& Weil, M. (2000). Model of Teaching. New York: Englewood Cliffs Prentice Hall

Kemendikbud. (2015). Angka Partisipasi ABK dalam Pendidikan Nasional. Jakarta: Kemendikbud

Khalid, S. (2010). Pembelajaran Kooperatif Model Investigasi Kelompok, Gaya Kognitif, dan Hasil Belajar Geografi. Jurnal Ilmu Pendidikan, 17(1), 73-78.

Marsh, C. (1991). Social Studies. Australia: Prentice Hall

Morina, A. (2016). Inclusive education in higher education: challenges and opportunities. European Journal Of Special Needs Education. 32(1), 3-17 